\title{
NEW SPECIES AND NEW COMBINATIONS IN GOODENIACEAE AND CAMPANULACEAE
}

\author{
R. C. CAROLIN
}

(Accepted for publication 15.1.1980)

\section{ABSTRACT}

Carolin, R. C. (John Ray Herbarium, University of Sydney, Australia 2006) 1980. New species and new combinations in Goodeniaceae and Campanulaceae. Telopea 2 (1): 63-75.-The following new species are described: Isotoma luticola (Campanulaceae) Goodenia centralis, G. rupestris, G. wilunensis, G. peacockiana, G. schwerinensis, $G$. suffrutescens, $G$. angustifolia, $G$. gibbosa, $G$. megasepala, $G$. iyouta, $G$. occidentalis, G. faucium, G. virgata, G. triodiophila, G. stellata, Scaevola basedowit, and Coopernookia scabridiuscula (Goodeniaceae). The new name Goodenia krauseana is supplied for Goodenia nana Krause non De Vriese, and the new combination Verreauxia verreauxii (De Vriese) Carolin is made for $V$, paniculata Benth.

\section{INTRODUCTION}

A number of species of Goodenia are here described for the first time and a new combination provided in that genus. These, together with other undescribed species and necessary new combinations, have become evident during a revision of the genus as a whole which will be published in the future. The names supplied here, unlike the remaining undescribed taxa etc., are required for the forthcoming Flora of Central Australia which is likely to be published before the generic revision. The species are referred to by their position in Krause's system (Krause, 1912), although this needs some revision.

One new species of Isotoma and one of Scaevola from the central Australian area are described for the first time. The opportunity is also taken here to describe a new species of Coopernookia and to make a new combination in Verreauxia.

\section{Isotoma luticola Carolin, sp. nov.}

HolotyPe: $3 \mathrm{~km} \mathrm{n}$. Wauchope, $20^{\circ} 37^{\prime} \mathrm{S} ., 134^{\circ} 14^{\prime}$ E., P.K. Latz 5152, 11.6.1974 (NT 43754).

Herba prostrata pilis paucis instructa caulibus ad $25 \mathrm{~cm}$ longis. Folia sessilia oblonga ad elliptica usque ad $1.5 \mathrm{~cm}$ longa dentibus crassis instructa. Flores in pedunculis ad $3 \mathrm{~cm}$ longis ex axillis foliorum distalium natis. Corolla lilacina ad caerulea vel violacea tubis circiter $5 \mathrm{~mm}$ longis. Tubus antherarum setis pluribus in orificio sed duabus earundum reliquibus ad 2-plo longioribus. Capsula globularis ad obconica 4-6 mm longa.

Prostrate herb with a few scattered hairs on the stems and leaves. Stems up to $25 \mathrm{~cm}$ long. Leaves sessile, oblong to elliptic, up to $15 \mathrm{~mm}$ long and $10 \mathrm{~mm}$ wide, coarsely toothed. Flowers borne on almost glabrous peduncles up to $3 \mathrm{~cm}$ long in the axils of the upper leaves. Sepals $1.5-2 \mathrm{~mm}$ long. Corolla lilac to blue or violet but becoming paler towards the base: tube c. $5 \mathrm{~mm}$ long: lobes spreading, $2-3 \mathrm{~mm}$ long. Anther tube c. $1.5 \mathrm{~mm}$ long with a number of bristles at the orifice, of which 2 of the lower ones are $1 \mathrm{~mm}$ long and thus much longer than the others. Capsule globular to obconic, 4-6 mm long, dehiscing through two valves. Seeds numerous.

This species occurs in muddy situations or damp earth on the margins of creeks and water pools in the Northern Territory.

The specific epithet refers to its normal habitat on mud or damp earth.

Specimens Examined: Northern Territory: Long Hole, $30 \mathrm{~m}[48 \mathrm{~km}] \mathrm{NW}$. Willowra HS., $G$. Chippendale, 30.7.1958 (NT 4741); Hanson River, $R$. Rawlins, 21.4.1962 (NT 8832); Stirling Stn. $21^{\circ} 47^{\prime} \mathrm{S}, 133^{\circ} 43^{\prime} \mathrm{E}$, A. S. Mitchell 043, 3.7.1974 (NT 42084); Marqua Stn., $22^{\circ} 39^{\prime} \mathrm{S}$, $137^{\circ} 10^{\prime}$ E, P. K. Latz 2625, 25.5.1972 (NT 35142); Curlew W. H., Lander River, G. Chippendale. 31.7 .1958 (NT 4801). 
Goodenia krauseana Carolin, nom. nov.

RePlaced Synonym: Goodenia nana Krause, Pflanzenr. 54: 80 (1912) nom. illeg. non De Vriese, Nat. Verh. Holl. Maats, Wet. Haarlem, 10: 132 (1854), which is a taxonomic synonym of Goodenia humilis $\mathrm{R}$. $\mathrm{Br}$. The species is named in honour of K. Krause who revised the family in 1912 for Das Pflanzenreich.

\section{Goodenia rupestris Carolin, sp. nov.}

HoLOTYPE: un-named pass between Hull and Docker Rivers, Petermann Ranges, Northern Territory, $R$. Carolin 5333, 21.8.1966 (NSW). IsoTYPE: SYD.

Herba gossypine tomentosa ascendens vel pendula caulibus latis condensatis. Folia elliptica vel anguste elliptica vel anguste obovata usque ad $6 \mathrm{~cm}$ longa integra basin versus sensim in petiolum indistinctum contracta. Flores in racemis foliosis dispositi: bracteolae lineares, $4-5 \mathrm{~mm}$ longae: pedicellus non articulatus. Corolla flava sacco obsoleto atque seriebus enationum obscurarum munita: lobi superiores alis $1.5 \mathrm{~mm}$ latis auriculatis. Ovulae 16-20. Indusium depresse obovatum, $1 \mathrm{~mm}$ longum setis super labiis affixis. Capsula elliptica $6 \mathrm{~mm}$ longa valvis duabus profunde bifidis erectis dehiscens. Semina ignota.

Ascending or pendulous perennial herb with a thick well-developed stock and scapes to $20 \mathrm{~cm}$ long. Leaves elliptic to narrow-obovate, $2-6 \mathrm{~cm}$ long, narrowing very gradually towards the base, entire, acute, cottony-tomentose on both surfaces but less so on the upper one and often glabrescent; leaves on the scape smaller and often sessile. Flowers arranged in terminal leafy racemes with bracteolate pedicels up to $1.2 \mathrm{~cm}$ long. Sepals linear-deltoid, $4-5 \mathrm{~mm}$ long, adnate to the ovary almost to its summit. Corolla yellow, 14-16 mm long, cottony-tomentose outside, villous inside with some small enations, anterior pouch almost obsolete; superior lobes auriculate. Style 5-6 mm long; indusium depressed-obovate or semi-orbicular, c. $2 \mathrm{~mm}$ wide slightly villous and with white bristles on the lips. Capsule ellipsoid, c. $6 \mathrm{~mm}$ long, 2-valved to the base each valve itself split half-way. Seeds not seen.

This species would be placed in ser. Rosulatae according to the classification of Krause (1912). The specific epithet refers to occurrence of this species on the cliffs of the Petermann Ranges in the Northern Territory which is its only recorded locality to date. It is a fairly distinct species, possibly related to $G$. xanthosperma $\mathrm{F}$. Muell. from which it can be distinguished by its entire leaves, perennial habit and the fact that the bristles around the orifice of the indusium are affixed on the lip rather than a short distance behind the lip.

\section{Goodenia peacockiana Carolin, sp. nov.}

Holotype: 23 miles from Yelma on the Leonora road, Western Australia, $R$. Carolin 59ll, 27.7.1967 (NSW). ISOTYPE: SYD.

Herba prostrata vel decumbens probabiliter annua. Caules condensati rosula persistenti foliorum: scapi usque ad $25 \mathrm{~cm}$ longi pilis arachnoideo-multicellularis paucis. Folia elliptica usque ad anguste obovata $2-6 \mathrm{~cm}$ longa, usque ad $1.2 \mathrm{~cm}$ lata versus basin sensim in petiolum indistinctum contracta dentata plus minusve lobata glabra vel pilis multicellularis paucis instructa. Flores bracteolis linearibus pedicellisque non articulatis in racemis foliosis dispositi. Corolla flava saepe nota porphyrea instructa circa $15 \mathrm{~mm}$ longa sacco $1 / 4$ longitudinem ovarii aequanti atque seriebus enatiorum munita. Lobi corollae superiores alis $2.5 \mathrm{~mm}$ latis instructi et auriculati. Dissepimentum ovarii duas partes longitudinis loculi aequans. Indusium late obovatum plicatum setis super labis affixis. Fructum obovoideum vel ellipsoideum duabus valvis dehiscens. Semina elliptica manifeste papillata ora crassa sed ala angustissima. 
Prostrate to decumbent probably annual herb with a thin taproot. Scapes up to $25 \mathrm{~cm}$ long sprinkled with arachnoid multicellular hairs. Leaves elliptic to narrowobovate, $2-6 \mathrm{~cm}$ long, dentate to \pm lobed, glabrous or with a few scattered hairs when young; leaves on the scape smaller, often sessile and with a pronounced basal lobe on one side only. Flowers arranged in terminal leafy racemes with glabrous peduncles $5-10 \mathrm{~cm}$ long, bracteolate. Sepals lanceolate, $6 \mathrm{~mm}$ long. Corolla yellow, often with brownish-purple markings, c. $15 \mathrm{~mm}$ long, pubescent towards the base outside but \pm glabrous towards the top outside, pubescent and with rows of enations inside and with an obscure pouch; superior lobes auriculate. Ovary cottonytomentose with a dissepiment two-thirds as long as the loculus and bearing c. 36 ovules; style $3 \mathrm{~mm}$ long; indusium broad-ovate, $2 \mathrm{~mm}$ wide, villous and with white bristles on the lips. Capsule obovoid to cylindrical, c. $10 \mathrm{~mm}$ long, dehiscing through 2 gaping valves. Seeds flattened, elliptic, $1.3 \mathrm{~mm}$ long, dark brown, prominently aculeate to setose and with a prominent rim but a very narrow wing.

This species would be placed in ser. Rosulatae Krause. It has been confused with Goodenia xanthosperma F. Muell. but differs in having a basal lobe on the cauline leaves and in the lack of a dense tomentum on the undersurface of the leaves. It is found only in Western Australia. The specific epithet refers to my friend Dr. W. J. Peacock, who has accompanied me on collecting expeditions and has contributed to our knowledge of the cytology of the Goodeniaceae.

\section{Goodenia wilunensis Carolin, sp. nov.}

Holoty PE: 25 miles $(40 \mathrm{~km})$ W. of Wiluna, Western Australia, C. A. Gardner 2382, 23.7.1931. (PERTH). ISOTYPE: BM.

Herba ascendens vel decumbens vel prostrata villosa annua. Scapi usque ad 30 $\mathrm{cm}$ longi. Folia rosulata elliptica vel obovata $4-6 \mathrm{~cm}$ longa $8-15 \mathrm{~mm}$ lata, gossypine villosa pilis simplicibus multicellularibusque, dentata acuta basim versus sensim in petiolum indistinctum decrescentia. Flores in racemis foliosis dispositi: pedicelli $3-6 \mathrm{~cm}$ longi; bracteolae anguste ovatae $4 \mathrm{~mm}$ longae. Sepala anguste ovata $6 \mathrm{~mm}$ longa acuta in dimidio inferiore ovarii affixa. Corolla flava circa $18 \mathrm{~mm}$ longa villosa extus atque in fauce intus pubescens: lobi superiores late alati auriculati prominentes. Dissepimentum ovarii dimidium longitudinem loculi aequans. Indusium transverse semiellipticum $1 \mathrm{~mm}$ longum 3-5 $\mathrm{mm}$ latum in plica dense villosum orificio recto. Capsula globularis vel subglobularis $7 \mathrm{~mm}$ longa $5 \mathrm{~mm}$ lata. Semina plana straminea ora alata atque indistinctissima.

Ascending to decumbent or prostrate herb. Scapes up to $30 \mathrm{~cm}$ long, terete, villous. Leaves mostly basal, elliptic to obovate, $4-6 \mathrm{~mm}$ long, narrowing gradually towards the base, dentate, acute, villous; leaves on the scape somewhat smaller. Flowers in leafy racemes on pedicels $3-6 \mathrm{~cm}$ long with two narrow bracteoles c. $4 \mathrm{~mm}$ long. Sepals narrow-ovate, $6 \mathrm{~mm}$ long, villous, adnate to the ovary for about half its length. Corolla yellow with violet markings, c. $18 \mathrm{~mm}$ long, villous outside, pubescent inside in the throat with an obscure pouch; superior lobes auriculate. Ovary with a dissepiment about half the length of the loculus; indusium transversesemi-elliptic, $3.5 \mathrm{~mm}$ wide, villous and with white bristles on the lips. Capsule subglobular, $7 \mathrm{~mm}$ long, dehiscing through two entire valves. Seeds flattened, yellowish-brown with a distinct rim but an indistinct narrow wing.

This species would be placed in ser. Rosulatae according to Krause's (1912) classification. It is a distinctive species and can be distinguished from all other members of that section by the villous hairs and the narrow-ovate sepals which are affixed to the lower half of the ovary. The specific epithet refers to the locality of the type collection. 
Goodenia centralis Carolin, sp. nov.

Holotype: 1.5 miles $(2.5 \mathrm{~km})$ E. Irving Creek, Petermann Range, Northern Territory, G. Chippendale, 24.6.1958 (NT 4643). IsotyPE: NSW 98788.

Herba prostrata radice tenui sparsim araneoso-pubescens pilis multicellularibus saepe glabrescens. Scapi usque $80 \mathrm{~cm}$ longi. Folia obovata vel spathulata, $3-10 \mathrm{~cm}$ longa, $1.5-3 \mathrm{~cm}$ lata grosse dentata basim versus sensim in petiolum indistinctum contracta. Flores in racemis foliosis dispositi: bracteolae lineares: pedicellus non articulatus. Corolla flava sacco quam ovario $1 / 3$ plo longiore atque seriebus enationum munita: lobi superiores alis $1.5 \mathrm{~mm}$ latis auriculatis instructi. Ovulae 28-30. Indusium depresse obovatum, $1 \mathrm{~mm}$ longum setis post labium affixis. Capsula elliptica vel ovoidea circa $8 \mathrm{~mm}$ longa duabus valvis bifidis erectis dehiscens. Semina plana oblonga.

Prostrate annual herb with scapes up to $80 \mathrm{~cm}$ long. Leaves obovate to spathulate, $3-10 \mathrm{~cm}$ long, arachnoid-pubescent but often sparsely so and often glabrescent, coarsely dentate, obtuse or terminated by a tooth. Flowers arranged in long leafy racemes on bracteolate pedicels up to $6 \mathrm{~cm}$ long. Sepals linear-deltoid, c. $2 \mathrm{~mm}$ long, adnate to the ovary almost to its summit. Corolla yellow sometimes with purplish markings, $12-15 \mathrm{~mm}$ long, sparsely arachnoid-pubescent outside and pubescent with rows of enations inside; anterior pouch indistinct, superior lobes auriculate. Ovary arachnoid-pubescent with a dissepiment about two-thirds as long as the loculus and bearing 28-30 ovules; style c. $6 \mathrm{~mm}$ long, villous; indusium depressed-ovate, $2 \mathrm{~mm}$ wide, villous and with white bristles on the lips. Capsule ovoid to ellipsoid, c. $8 \mathrm{~mm}$ long, dehiscing through two valves which themselves sometimes divide to their middle. Seeds flattened, yellow-brown, oblong, $2.5 \mathrm{~mm}$ long, minutely aculeate with a distinct rim but a narrow wing.

This species has been previously confused with Goodenia rotundifolia $\mathrm{R}$. Br. but it differs from the latter in having arachnoid rather than stiff simple hairs on the leaves and stems. It would be placed in ser. Rosulatae Krause. The specific epithet refers to the distribution of the species in central Australia where it occurs in a variety of soil types in Western Australia and the Northern Territory.

\section{Goodenia schwerinensis Carolin, sp. nov.}

Holoty D. E. Symon 2431, 2.8.1962 (PERTH). IsOTYPE: ADW.

Herba decumbens vel ascendens confertim pubescens pilis simplicibus et multicellularibus. Caules condensati. Scapi usque $40 \mathrm{~cm}$ longi in axillis foliorum rosulatorum inserti. Folia rosulata anguste elliptica vel anguste oblonga vel anguste obovata $5-12 \mathrm{~cm}$ longa $1-2 \mathrm{~cm}$ lata dentata vel lyrata basim versus in petiolum contracta. Folia scaporum basi lobo solitario instructa. Flores in racemis foliosis dispositi pedicellis non articulatis bracteolisque linearibus. Corolla flava sacco fere obsoleto et seriebus enatiorum munita. Lobi superiores corollae auriculati alis circa $1 \mathrm{~mm}$ latis. Indusium depresse obovatum plicatum setis super labiis affixis. Fructus ovoideus circa $10 \mathrm{~mm}$ longus duabus valvis integris erectis crassiusculis dehiscens. Semina plana setosa elliptica ora crassa sed ala fere obsoleta.

Prostrate to decumbent or ascending herb with scapes up to $40 \mathrm{~cm}$ long. Basal leaves narrow-elliptic to narrow-obovate, $5-12 \mathrm{~cm}$ long, pubescent, dentate to lyrate, narrowing very gradually towards the base; leaves on the scapes narrower and almost sessile with a lobe on one side at the base. Flowers arranged in a leafy raceme on pedicels up to $3.5 \mathrm{~cm}$ long; bracteoles linear, $4-5 \mathrm{~mm}$ long. Sepals linear-deltoid, 6-7 mm long. Corolla yellow, 12-15 mm long, pubescent outside with mostly simple hairs, pubescent inside and with rows of many prominent enations; anterior pouch almost obsolete; superior lobes auriculate. Ovary pubescent with a dissepiment up to three-quarters the length of the loculus and bearing 28-30 ovules; 
style glabrous, $5 \mathrm{~mm}$ long; indusium depressed-ovate, $2.5 \mathrm{~mm}$ wide, villous and with white bristles on the lips. Capsule c. $10 \mathrm{~mm}$ long, dehiscing through two entire thick erect valves. Seeds flattened, elliptic, brown, $3 \mathrm{~mm}$ long, aculeate with a thickened rim but an indistinct wing.

This species would be placed in ser. Rosulatae Krause close to Goodenia glabra R. Br. from which it differs in its densely pubescent leaves. It occurs in Western Australia and the southwest of the Northern Territory. The specific epithet is taken from the Schwerin Mural Crescent near which it occurs.

\section{Goodenia suffrutescens Carolin, sp. nov.}

Holotype: 30 miles $(48 \mathrm{~km}) \mathrm{S}$. of Halls Creek, Billiluna Station, Western Australia, $R$. Carolin 7915, 22.8.1970 (NSW). IsOTYPES: SYD, PERTH.

Suffrutex usque $1 \mathrm{~m}$ altus. Folia oblanceolata ad obovata $8-11 \mathrm{~cm}$ longa pubescentia \pm viscidia pilis glandulosis dentataque. Flores in racemis foliosis terminalibus dispositi. Pedunculi usque ad $2 \mathrm{~cm}$ longi bracteolis ovato-elliptica (2-) 6-15 mm longis sessilis. Pedicelli usque ad $5 \mathrm{~cm}$ longi indistincte articulati. Sepala lanceolata $3 \mathrm{~mm}$ longa. Corolla coerulea $15-20 \mathrm{~mm}$ longa pubescens, pilis glandulosis confertis atque paucis simplicibus extus etiam pilis paucis longis rigidis intus margines loborum inferiorum versus. Saccus corollae et enationes prominentes. Ovarium glandulose pubescens dissepimento tres partes longitudinis loculi aequanti. Indusium oblongum $2 \mathrm{~mm}$ longum villosum setis albido-purpurascentibus super labiis. Capsula ovoidea usque cylindrica $1 \mathrm{~cm}$ longa duabus valvis integris dehiscens.

Sub-shrub up to $1 \mathrm{~m}$ tall, the stems sometimes decumbent. Leaves usually \pm clustered at the base of the scapes, oblanceolate to obovate, $8-11 \mathrm{~cm}$ long, glandularpubescent and viscid, irregularly dentate and tapering very gradually towards the base. Flowers arranged in terminal leafy thyrses; peduncles up to $2 \mathrm{~cm}$ long; bracteoles obovate to elliptic, 6-14 $\mathrm{mm}$ long; pedicels up to $5 \mathrm{~mm}$ long. Sepals lanceolate, c. $3 \mathrm{~mm}$ long. Corolla blue, $15-20 \mathrm{~mm}$ long, densely glandular-pubescent outside with a few simple hairs and with some long stiff white hairs and very prominent enations inside; superior lobes enclosing the indusium but only indistinctly auriculate; anterior pouch prominent and as long as the ovary. Ovary glandularpubescent with a dissepiment three-quarters as long as the loculus and bearing up to 40 ovules; style $8-9 \mathrm{~mm}$ long, villous; indusium oblong, $2 \mathrm{~mm}$ wide, villous and with white to purplish bristles on the lips. Capsule ovoid to cylindrical, c. $1 \mathrm{~cm}$ long, dehiscing through two entire valves.

According to Krause (1912), this species would be placed in ser. Caerulea Benth. close to $G$. scaevolina $F$. Muell. It differs from that species in having broader bracteoles, coarser glandular hairs and the superior lobes of the corolla enclosing the indusium. It is only known from the Tanami desert on the borders of Western Australia and Northern Territory. The specific epithet refers to the sub-shrubby habit of the plant.

\section{Goodenia angustifolia Carolin, sp. nov.}

Holotype: Nockatunga, Queensland, R. Carolin 4159, 8.1964 (NSW).

Herba erecta vel ascendens usque ad $25 \mathrm{~cm}$ alta, glauca. Folia basalia linearia teretia canaliculata integra sessilia $5-8 \mathrm{~cm}$ longa. Folia caulina subfasciculata quam folia basalis aliquantum breviora. Flores in racemis brevibus vel umbellis dispositi pedunculus 5-10 mm longis bracteolisque lineari-deltoideis $1-1.5 \mathrm{~mm}$ longis. Sepala oblongo-lanceolata $2.5-3 \mathrm{~mm}$ longa. Corolla flava $10-12 \mathrm{~mm}$ longa glabra extus simpliciter pubescens ac intus glandulose. Lobi superiores corollae auriculi unde ala inferiore sino longo disjuncti: Dissepimentum ovarii tertiam longitudinem loculi aequans. Indusium transverse oblongum $1.5 \mathrm{~mm}$ longum convexum setis albis usque $0.3 \mathrm{~mm}$ longis super labiis munitum. Capsula et semina ignotae. 
Erect or ascending herb up to $25 \mathrm{~cm}$ high. Leaves basal and cauline the latter tending to be fasciculate, linear, terete and channelled, thick, glabrous, \pm glaucous, $5-8 \mathrm{~cm}$ long; cauline leaves somewhat shorter. Flowers arranged in short terminal racemes or umbellate on glabrous pedicels 5-10 $\mathrm{mm}$ long; bracteoles linear-deltoid, c. $1 \mathrm{~mm}$ long. Sepals oblong-lanceolate, entire, acute, glabrous, c. $3 \mathrm{~mm}$ long. Corolla bright yellow, 10-12 $\mathrm{mm}$ long, glabrous outside with an indistinct pouch; superior lobes auriculate with the auricle separated from the wing by a deep long sinus. Ovary glabrous, glaucous with a dissepiment c. one-third as long as the loculus and bearing c. 24 ovules; style $3 \mathrm{~mm}$ long, glabrous; indusium transverse-oblong, $2 \mathrm{~mm}$ wide, convex with a tuft of villous hairs on either side and white bristles around the orifice.

According to Krause's system this species would be placed in ser. Pedicellosae Benth. close to Goodenia glauca F. Muell. It can be distinguished from G. glauca in having linear-terete leaves. It is known only from the type collection. The specific epithet refers to the narrow leaves.

\section{Goodenia gibbosa Carolin, sp. nov.} (NSW).

Holotype: South end of Dean Range, Western Australia, R. C. Carolin 6071, 5.8.1967

Herba prostrata vel decumbens saepe stolonifera. Folia elliptica usque ad oblanceolata (2-) 5-8 cm longa \pm simpliciter molliterque pubescentia, dentata vel integra basim versus sensim contracta, in rosulis in caulorrhiza vel in stolonibus disposita. Flores in racemis vel umbellis foliosis vel in axillis foliorum basalium dispositi pedunculis glabris vel plus minusve molliter pubescentibus articulatis post casum capsularum persistentibus. Sepala lanceolata vel ovata $2-3 \mathrm{~mm}$ longa. Corolla flava $12-17 \mathrm{~mm}$ longa glabra vel extus sparsissime pubescens vel intus pubescens, sacco prominentissimo ovarium aequanti. Lobi superiores corollae auriculati. Ovarium dissepimento longitudine vix dimidiam longitudinem loculi aequanti. Indusium transverse oblongum $1.5 \mathrm{~mm}$ longum barbellatum infra atque setis albidis $0.5 \mathrm{~mm}$ longis super labro superiore munitum. Capsula globularis vel subglobularis 5-6 mm diametro duabus valvis dehiscens. Semina orbicularia $3 \mathrm{~mm}$ diametro reticulata ala sordida circa $5 \mathrm{~mm}$ lata.

Prostrate to decumbent herb with basal group of leaves and further tufts on the ends of short stolons. Leaves elliptic to obovate or oblanceolate, $5-8 \mathrm{~cm}$ long, sprinkled with soft appressed or spreading simple hairs, dentate to almost entire, tapering very gradually towards the base; cauline leaves smaller than the basal ones. Flowers arranged in leafy racemes or in umbels or solitary in the axils of the leaves. Sepals lanceolate to ovate, $2-3 \mathrm{~mm}$ long, adnate to the ovary for c. two-thirds of its length. Corolla yellow, 12-17 mm long, glabrous outside or with a few scattered hairs; anterior pouch prominent and as long as or slightly longer than the ovary; superior lobes auriculate. Ovary glabrous with a dissepiment c. half as long as the loculus and bearing c. 20 ovules; style $5 \mathrm{~mm}$ long; indusium transverse-oblong, $2.5 \mathrm{~mm}$ wide, villous and with white bristles around the lips. Capsule globular or nearly so, 5-6 $\mathrm{mm}$ diam., dehiscing through two entire valves. Seeds flattened, orbicular, c. $3 \mathrm{~mm}$ diam., black, reticulate-foveate, with a distinct rim and a greyish wing.

This species would be placed in ser. Pedicellosae Benth. according to the system of Krause (1912), and has affinities with $G$. pinnatifida Schlechtd., from which it can be distinguished by a much more marked stoloniferous habit, a much more pronounced corolla pouch and the pedicels persistent long after the valves of the capsule have fallen. It occurs in Western Australia and the Northern Territory and is common in the central Australian area. The specific epithet refers to the gibbous appearance of the inferior ovary due to the presence of the corolla pouch. 
Goodenia megasepala Carolin, sp. nov.

HolotyPE: Beale Range, Queensland, K. A. Williams 78202, 8.1978 (BRI 264700).

Herba prostrata vel decumbens substolonifera. Folia oblanceolata vel anguste elliptica $2-10 \mathrm{~cm}$ longa hirsuta dentata vel pinnatisecta basim versus sensim in petiolum indistinctissimum contracta in rosula basali vel in caespite caulini disposita. Flores in pseudoumbellis foliosis terminalibus dispositi pedunculis $4-6 \mathrm{~cm}$ longis ebracteolatis indistincte articulatis. Sepala anguste elliptica vel lanceolata $6-8 \mathrm{~mm}$ longa. Corolla flava c. $18 \mathrm{~mm}$ longa hirsuta extus et basi pubescens intus. Ovarium hirsutum dissepimento circa dimidiam longitudinem loculi aequante. Indusium transverse oblongum $1.5 \mathrm{~mm}$ longum setis albidis super labiis munitum. Capsula globularis c. $6 \mathrm{~mm}$ diametro duabus valvis integris tarde secedentibus. Semina plana reticulata alis angustis.

Prostrate to decumbent herb with a stout tap-root. Scapes pubescent, up to $25 \mathrm{~cm}$ long. Leaves mostly basal, oblanceolate to narrow-elliptic in outline, $2-10 \mathrm{~cm}$ long, pubescent, dentate or pinnately lobed, tapering very gradually towards the base. Flowers arranged in leafy umbel-like racemes on pedicels up to $6 \mathrm{~cm}$ long, ebracteolate. Sepals narrow-elliptic to lanceolate, $6-8 \mathrm{~mm}$ long, $1.5 \mathrm{~mm}$ wide. Corolla yellow, c. $18 \mathrm{~mm}$ long, pubescent-hirsute outside, pubescent inside especially towards the base; anterior pouch obscure; superior lobes auriculate. Ovary pubescent with a dissepiment c. half as long as the loculus and bearing c. 30 ovules; style c. $6 \mathrm{~mm}$ long; indusium transverse-oblong, $3.5 \mathrm{~mm}$ wide, convex, with a few scattered villous hairs and some white bristles on the lips. Capsule globular, c. $6 \mathrm{~mm}$ diam., hirsute, dehiscing through two entire valves. Seeds flattened with a broad wing and prominent rim.

This species would be placed in ser. Pedicellosae Krause, although its affinities within that series are obscure. It is possibly related to G. fascicularis F. Muell. \& Tate, from which it can be distinguished by the larger broader sepals from which the specific epithet is derived, and the hairs on the leaves and stems which are not strigose. It is known only from the region close to Windorah in Queensland.

\section{Goodenia iyouta Carolin, sp. nov.}

HolotyPE: near Notabilis Hill, Gunbarrel Highway, Western Australia, E. Bettenay 25, 7.1965 (PERTH).

Herba prostrata. Caules usque $120 \mathrm{~cm}$ longi hirsuto-pubescentes. Folia basalia ignota. Bracteae ovatae vel ellipticae dentatae plus minusve pubescentes basim versus sensim in petiolum indistinctum usque ad $1 \mathrm{~cm}$ longum attenuatae. Flores in racemis longis foliosis dispositi pendunculis usque ad $4 \mathrm{~cm}$ longis ebracteolatis et non articulatis. Sepala anguste oblonga circa $3.5 \mathrm{~mm}$ longa pro dimidio longitudine ovarii affixa. Corolla flava $11-14 \mathrm{~mm}$ longa simpliciter glanduloseque brevissime pubescens extus sacco prominenti longitudinem ovarii aequante. Lobi superiores corollae indistinctissime auriculati. Ovarium pubescens tertiam longitudinem loculi aequanti. Indusium transverse oblongum $1.5 \mathrm{~mm}$ longum setis albidis $0.1 \mathrm{~mm}$ longis super labiis. Capsula subglobularis $5-6 \mathrm{~mm}$ diametro pubescens duabus valvis integris ad basim dehiscens. Semina orbicularia $3.5 \mathrm{~mm}$ diametro reticulata fusca nigrave ala brunnea pallide circa $0.5 \mathrm{~mm}$ lata.

Prostrate or ascending herb with stems up to $120 \mathrm{~cm}$ long. Basal leaves ephemeral; cauline leaves ovate to elliptic, up to $2 \mathrm{~cm}$ long, dentate, pubescent with mostly simple hairs but a few glandular ones also present, tapering very gradually towards the base. Flowers arranged in terminal leafy racemes on ebracteolate pedicels up to $4 \mathrm{~cm}$ long. Sepals narrow-oblong, c. $3.5 \mathrm{~mm}$ long. Corolla yellow, 11-15 mm long, simple- and glandular-pubescent outside and simple-pubescent inside particularly in the throat; anterior pouch prominent, about as long as the ovary; superior lobes auriculate. Ovary pubescent with simple and minute glandular hairs and with a dissepiment $c$. one-third as long as the loculus and bearing c. 15 ovules; 
style 4-5 mm long; indusium transverse-oblong, $3 \mathrm{~mm}$ wide. Capsule subglobular, slightly compressed, 5-6 $\mathrm{mm}$ diam., dehiscing through two entire valves. Seeds flattened, orbicular, $3.5 \mathrm{~mm}$ diam., dark brown to almost black, reticulate-foveate, with a distinct rim and a thick pale brown wing.

This species might be placed in ser. Foliosae Benth. according to Krause's system but it shows no close affinity with any other species. It is known only from the drier parts of Western Australia. The specific epithet is an aboriginal word for Triodia spp., with which this species is frequently found growing; the epithet is indeclinable.

\section{Goodenia occidentalis Carolin, sp. nov.}

HoLOTYPE: 140 miles $(224 \mathrm{~km}) \mathrm{W}$. of the Warburton Range on the road to Laverton, Western Australia, $R$. Carolin 5936, 27.7.1967 (NSW).

Herba prostrata vel decumbens. Caules usque ad $40 \mathrm{~cm}$ longi glabrescentes. Folia oblanceolata $2-8 \mathrm{~cm}$ longa plus minusve crasse dentata usque lyrata vel interdum integra pubescentia pilis simplicibus appressis basim versus sensim contracta. Flores in racemis secundis terminalibus dispositi, bracteis linearilanceolatis vel linearibus, pedunculis arcuatis ebracteolatis articulatis. Corolla flava sed interdum brunneo-purpurascens basim versus simpliciter pubescens extus sacco indistincto. Ovarium glabrum vel sparse glandulose ac simpliciter pubescens dissepimento circa quartum longitudinem loculi aequanti. Capsula globularis usque ad $3 \mathrm{~mm}$ diametro per duas valvas integras dehiscens. Semina orbicularia circa $2 \mathrm{~mm}$ diametro nigra nitida reticulata ala hyalina $0.5 \mathrm{~mm}$ lata qua partem corporis imbricata.

Prostrate to decumbent herb with scapes up to $40 \mathrm{~cm}$ long. Leaves mostly basal, oblanceolate, $2-8 \mathrm{~cm}$ long, thick, pubescent with appressed simple hairs, dentate to lyrate or sometimes almost entire, tapering very gradually towards the base. Flowers arranged in terminal racemes, sometimes \pm secund with lincar to linearlanceolate bracts; pedicels $6-10 \mathrm{~mm}$ long, ebracteolate. Sepals ovate or lanceolate 1-1.6 mm long, adnate to the ovary for c. two-thirds of its length. Corolla yellow often becoming purplish-brown towards its base, 4-6 mm long; anterior pouch not prominent; superior lobes auriculate. Ovary glabrous or nearly so with a dissepiment scarcely half as long as the loculus and bearing 20 ovules; style c. $1.5 \mathrm{~mm}$ long; indusium depressed-ovate, $1-1.2 \mathrm{~mm}$ wide, villous and with white bristles on the lips. Capsule globular $2.5-3 \mathrm{~mm}$ diam., dehiscing through two entire valves. Seeds biconvex, orbicular, c. $2 \mathrm{~mm}$ diam., black with an overlapping hyaline mucilaginous wing.

This species would probably be placed in ser. Pedicellosae Benth. according to Krause's system. It has been confused with $G$. filiformis De Vriese in the past but it lacks the distinct corolla pouch of the latter and the wing of the seed overlaps the body. The specific epithet refers to its chiefly western distribution, although it has been collected in New South Wales and South Australia.

\section{Goodenia faucium Carolin, sp. nov.}

HolotyPE: Gorge near Mt. Liebig, Northern Territory, G. Chippendale 3556, 23.7.1957 (NT). ISOTYPES: CANB, MEL.

Suffrutex viscidus caulibus erectis vel ascendentibus usque $40 \mathrm{~cm}$ altis. Folia obovata lanceolata vel anguste elliptica usque ad $3.5 \mathrm{~cm}$ longa viscida pilis minutis peltatis ad basim sensim contracta plerumque sessilia. Flores in racemis foliosis terminalibus dispositi pedunculis ebracteolatis articulatis. Sepala anguste elliptica vel lanceolata $4 \mathrm{~mm}$ longa. Corolla flava $14-15 \mathrm{~mm}$ longa viscida extus pubescens intus sacco duas partes longitudinem ovarii aequanti instructa. Lobi superiores corollae ala auriculata quam alia angustiore. Ovarium transverse oblongum $1 \mathrm{~mm}$ longum barbula villosa infra, et setis albidis $0.2-0.3 \mathrm{~mm}$ longis super labiis munitum. Capsula subglobularis $4.5 \mathrm{~mm}$ diametro duabus valvis integris dehiscens. Semina elliptica $3 \mathrm{~mm}$ longa ala angusta hyalina circa $0.2 \mathrm{~mm}$ lata. 
Perennial viscid subshrub with erect or ascending stems to $40 \mathrm{~cm}$ high. Leaves mostly cauline, obovate to narrow-elliptic, $1.5-3.5 \mathrm{~cm}$ long, covered with minute peltate hairs and thus apparently glabrous but viscid, dentate, acute, sessile or tapering very gradually into a short petiole. Flowers arranged in terminal leafy racemes on ebracteolate peduncles up to $15 \mathrm{~mm}$ long. Sepals narrow-elliptic to lanceolate, $4 \mathrm{~mm}$ long. Corolla yellow, 14-15 mm long, covered with minute viscid peltate hairs outside and with a distinct anterior pouch; superior lobes with unequal wings and auriculate. Ovary viscid with a dissepiment c. half as long as the loculus bearing c. 40 ovules; style $5 \mathrm{~mm}$ long, glabrous; indusium transverse-oblong, c. 2.5 $\mathrm{mm}$ wide, with a villous beard on the lower surface and white bristles on the lips. Fruit subglobular, $4.5 \mathrm{~mm}$ diam., dehiscing through two entire valves. Seeds flattened, elliptic, c. $3 \mathrm{~mm}$ long with a prominent rim and a narrow wing.

This species would be placed in ser. Foliosae Benth. in Krause's system. It shows some affinities with $G$. larapinta Tate but differs in having minute peltate hairs, rather than the long glandular hairs of $G$. larapinta. The specific epithet refers to the narrow valleys near Mt Liebig in the Northern Territory where this species appears to be confined.

\section{Goodenia virgata Carolin, sp. nov.}

HolotyPe: 73 miles $(117 \mathrm{~km})$ from Yuendumu on Alice Springs Road, Northern Territory, R. Carolin 7937, 24.8.1970 (NSW). IsOTYPE: SYD.

Herba erecta vel ascendens caulibus glabris vel pubescentibus sparse rigidis usque $40 \mathrm{~cm}$ altis. Folia basalia linearia ad oblanceolata $1-6 \mathrm{~cm}$ longa plus minusve crassa plana vel involuta glabra integra basim versus contracta vel admodum sessilia. Folia caulina parviora involuta plerumque linearia. Flores in pedunculis 15-25 mm longis glabris vel pubescentibus sparse ebracteolatis articulatis pulvinatis ad basim divergentibus vel capsuliferis etiam reflexis in racemis terminalibus dispositi. Sepala lineari-lanceolata $1.5-2 \mathrm{~mm}$ longa. Corolla flava $8-12 \mathrm{~mm}$ longa simpliciter ac glandulose pubescens extus. Ovarium simpliciter ac glandulose pubescens dissepimento quartum longitudinem loculi aequanti. Indusium transverse late oblongum $1.5 \mathrm{~mm}$ longum villosum setis albidis $0.4 \mathrm{~mm}$ longis super labiis munitum. Capsula globularis $7 \mathrm{~mm}$ diametro duabus valvis integris dehiscens. Semina orbicularia circa $2.5 \mathrm{~mm}$ diametro ala $0.8-1 \mathrm{~mm}$ lata.

Erect to ascending herb to $40 \mathrm{~cm}$ high. Leaves both basal and cauline, linear to oblanceolate, $1-6 \mathrm{~cm}$ long, glabrous or with a few simple hairs towards the top, thick, flat or terete, dentate or entire, sessile or nearly so; cauline ones usually linear. Flowers arranged in terminal racemes on ebracteolate peduncles up to $25 \mathrm{~mm}$ long; the peduncles divergent or patent in the fruiting stage and usually persistent after the valves of the capsule have fallen. Sepals linear-lanceolate, $1.5-2 \mathrm{~mm}$ long, adnate to the ovary for half to two-thirds of its length. Corolla yellow, 8-12 mm long, glandularand simple-pubescent outside, with a prominent anterior pouch; superior lobes with equal wings on either side, auriculate. Ovary glandular- and simple-pubescent with a dissepiment $c$. half as long as the loculus and bearing 6-14 ovules; style $4 \mathrm{~mm}$ long; indusium transverse-broad-oblong, $2 \mathrm{~mm}$ wide, villous on both surfaces with white bristles on the lips. Fruit globular, $7 \mathrm{~mm}$ diam., dehiscing through two entire valves. Seeds flattened, orbicular, c. $2.5 \mathrm{~mm}$ diam., grey, colliculate with a prominent rim and a wide wing.

This species would be placed in ser. Pedicellosae Benth. according to Krause's system. It resembles $G$. armitiana $F$. Muell., differing in having glabrous leaves and equal wings on the superior lobes of the corolla. It is known only from the Tanami Desert on the borders of the Northern Territory and Western Australia. The specific epithet refers to the appearance of the plant when the capsule valves have fallen from the pedicels; it then resembles a small shrub with bare twigs. 


\section{Goodenia triodiophila Carolin, sp. nov.}

Holotype: 74 miles (118 km) from Tom Price on Yampire Gorge Road, Western Australia, R. Carolin 7773, 9.8.1970 (NSW). IsOTYPE: SYD.

Herba erecta vel ascendens ramosissima caulibus rigidis usque $40 \mathrm{~cm}$ altis glabra vel glabrescens basibus nonnunquam exceptis. Folia linearia $4-10 \mathrm{~cm}$ longa teretia involuta sessilia glabra pro parte maxima. Flores in pedunculis $8-30 \mathrm{~mm}$ longis ebracteolatis articulatis glabris vel apicem versus sparse glandulose pubescentibus, in racemis terminalibus dispositi. Sepala lineari-lanceolata usque ad anguste ellipticooblonga $1.5-3 \mathrm{~mm}$ longa ad ovarium per $1 / 3-1 / 2$ longitudinus eius affixa. Corolla flava 10-12 mm longa extus simpliciter ac glandulose pubescens intus simpliciter pubescens sacco prominenti ovarium aequanti instructa. Ovarium dissepimento circa dimidiam longitudinem loculi aequanti. Indusium depresse ovatum $1.5-1.8 \mathrm{~mm}$ longum glabrum vel villosum setis brevis $0.1-0.2 \mathrm{~mm}$ longis super labiis munitum. Capsula globularis usque ovoidea circa $6 \mathrm{~mm}$ diametro duabus valvis integris dehiscens. Semina orbicularia $6 \mathrm{~mm}$ diametro reticulata ala straminea $1-1.5 \mathrm{~mm}$ lata.

Much branched stiff ascending or erect herb to $40 \mathrm{~cm}$ high. Stems reddish or brownish and pubescent towards the base but becoming green and glabrous towards the top. Leaves linear, 4-10 cm long, terete, involute, sessile, lowest ones with a few simple hairs but upper ones usually glabrous. Flowers in terminal racemes on ebracteolate peduncles up to $30 \mathrm{~mm}$ long. Sepals lanceolate to narrow-elliptic-oblong $1.5-3 \mathrm{~mm}$ long adnate to the ovary for one-third to a half of its length. Corolla yellow, 10-12 mm long, glandular and simple-pubescent outside; anterior pocket prominent; superior lobes with $\downarrow$ equal wings, auriculate. Ovary simple- and glandular-pubescent with a dissepiment half as long as the loculus and bearing 20-25 ovules; style $5-6 \mathrm{~mm}$ long, glabrous or villous; indusium depressed-ovate, c. $3 \mathrm{~mm}$ wide, pubescent on both surfaces and with white bristles on the lips. Fruit globular to ovoid, c. $6 \mathrm{~mm}$ diam., dehiscing through two entire valves. Seeds flattened, orbicular, 4-6 $\mathrm{mm}$ diam., reticulate-alveolate with a prominent rim and a broad wing.

This species would be placed in ser. Pedicellosae Benth. in Krause's system. It resembles $G$. armitiana $F$. Muell. but can be distinguished by the glabrous, longer leaves and the branched main stem. It is a common species throughout central Australia; occurring in Western Australia, Northern Territory and Queensland. The specific epithet refers to the fact that it frequently grows in hummocks of Triodia spp.

\section{Goodenia stellata Carolin, sp. nov.}

Holoty R. Carolin 7770, 9.8.1970 (NSW). ISOTYPE: SYD.

Herba decumbens vel prostrata pubescens pilis stellatis caulibusque usque $20 \mathrm{~cm}$ longis. Folia fere rosulata oblongo-elliptica usque ovata $4-8 \mathrm{~cm}$ longa 5-25 mm lata pubescentia crenato-dentata basim versus in petiolum plus minusve abrupte contracta: folia caulina similia sed parviora et fere sessilia. Flores in pedunculis pubescentibus ebracteolatis articulatis $10-20 \mathrm{~mm}$ longis, in racemis foliosis terminalibus dispositi. Corolla flava $12-15 \mathrm{~mm}$ longa stellate pubescens extus et basin versus simpliciter pubescens intus. Alae in margine utroque loborum corollae apicem vix attingentes eaeque in marginibus inferioribus loborum superiorum auriculatae. Stylus 6-7 mm longus glaber indusio transverse oblongo $1-1.5 \mathrm{~mm}$ longo. Capsula globularis 6-7 $\mathrm{mm}$ diametro pubescens duabus valvis integris dehiscens. Semina orbicularia circa $4 \mathrm{~mm}$ diametro nigras nitidula reticulata ala et ora vix insignibus. 
Decumbent to prostrate stellate-pubescent herb with stems to $20 \mathrm{~cm}$ long. Leaves mostly basal, oblong-elliptic to ovate, 4-8 cm long, crenate-dentate, obtuse, tapering \pm abruptly into a short petiole; cauline leaves smaller and almost sessile. Flowers arranged in terminal leafy racemes on ebracteolate peduncles $10-20 \mathrm{~mm}$ long. Sepals lanceolate to narrow-oblong, c. $4 \mathrm{~mm}$ long. Corolla yellow, 12-15 mm long, stellate-pubescent outside with an obscure anterior pouch; superior lobes auriculate with a slightly narrower wing on the auricle side than on the other. Ovary with a dissepiment $c$. two-thirds the length of the loculus and bearing 25-30 ovules; style 6-7 mm long, glabrous; indusium with a few hairs scattered over the surfaces and white bristles on the lips. Fruit globular, 6-7 mm diam., dehiscing through two entire valves. Seeds flattened, orbicular, c. $4 \mathrm{~mm}$ diam., black, glossy, minutely reticulate with a scarcely differentiated wing.

This species is of doubtful position in Krause's classification but would possibly be placed in ser. Foliosae Benth. It differs from all other members of that series in having stellate hairs on the leaves. It is known from the Pilbara Region and Gibson Desert of Western Australia. The specific epithet refers to the stellate hairs that cover the plant.

\section{Scaevola basedowii Carolin, sp. nov.}

Holotype: Mt Unapproachable, South Australia, H. Basedow 134, 1.7.1926 $(K)$. (Not the sheet marked 'SHT. 2 ...').

Planta erecta ramosa suffruticosa ad $60 \mathrm{~cm}$ alta. Caules glandulose pubescentes atque pilis simplicibus paucis instructis. Folia ovata ad triangulares plerumque ad $8 \mathrm{~mm}$ longa pilis glandulosis simplicibusque. Flores plerumque solitares, in pedunculis ad $5 \mathrm{~cm}$ longis in axillis foliorum bracteolis duabis parvus triangularibus. Sepala pilis glandularibus instructa in dimidio inferiore connata, 2-3 mm longa tubo includentibus. Corolla alba sed lineis fuscis notata, ad $2.2 \mathrm{~cm}$ longa, intus barba longa densa et extus pilis arcuatis antrorsis simplicibus instructa. Ovarium pilis glandulosis simplicibusque munitum. Indusium setis numerosis fusco-albis idem aequantibus vel superantibus. Fructus sicciter carnosus.

Erect subshrub to $60 \mathrm{~cm}$ high. Stems much-branched, glandular-pubescent and with some scattered stiff simple hairs, \pm ridged. Leaves ovate to triangular, mostly less than $8 \mathrm{~mm}$ long, 1-3 mm wide, acute to bluntly acuminate, pubescent as the stems. Flowers borne in the axils of the upper leaves; peduncles up to $5 \mathrm{~cm}$ long, similar to the stems; bracteoles 2, triangular-ovate, c. $3 \mathrm{~mm}$ long, opposite or slightly displaced and inserted in the upper third of the peduncle. Sepals glandular-pubescent with very few simple hairs, connate into a tube $2-3 \mathrm{~mm}$ long surmounted by the lobes which are 1-1.5 mm long. Corolla 15-22 $\mathrm{mm}$ long, white with brownish lines, pubescent with stiff antrorse-arcuate to appressed simple hairs outside, densely bearded below the lobes inside; lobes oblong-elliptic, 5-7 $\mathrm{mm}$ long, $1.5 \mathrm{~mm}$ wide with a wing on either side c. $1 \mathrm{~mm}$ wide; tube $10-15 \mathrm{~mm}$ long. Stamens with filaments 5-7 $\mathrm{mm}$ long; anthers oblong, c. $2 \mathrm{~mm}$ long with a short flattened terminal appendage. Ovary covered with short glandular hairs and long stiff white patent simple hairs. Fruit dry, drupe-like, up to $5 \mathrm{~mm}$ diam.

Specimens Examined: Northern Territory: Mt Ziel-northern base, G. W. Carr $1772 \&$ A. C. Beauglehole 45501,13.6.1974 (SYD); 17 miles $(27 \mathrm{~km}) \mathrm{S}$. of Mt. Wedge Station, M. Lazarides $6062,19.9 .1956$ (NSW); Camp 17 and 18 Elder Exploring Expedition, R. Helms 10.7.1891 (NSW 83096)

This species would be placed in ser. Pogonanthera G. Don according to Krause's system, close to Scaevola depauperata R. Br. and can be distinguished from related species by the characters shown in Table 1.

The specific epithet refers to the collector of the type specimen, Herbert Basedow (1883-1933), a South Australian geologist and anthropologist who took part in a number of expeditions into northern South Australia and the Northern Territory. 
TABLE 1

Diagnostic Features of S.basedowii and Related Species

\begin{tabular}{|c|c|c|c|c|}
\hline Species & $\begin{array}{l}\text { Indumentum } \\
\text { on stems }\end{array}$ & $\begin{array}{l}\text { Hairs on ovary } \\
\text { and corolla }\end{array}$ & Calyx & Distribution \\
\hline S. basedowii & $\underset{\text { simple }}{\text { glandular and }}$ & white, coarse & campanulate & N.T. \& drier parts of W.A. \\
\hline S. depauperata. & glabrous & white, short & campanulate & Qld, S.A., southern N.T. \\
\hline S. parvifolia & simple & whitish, stiff & deeply divided & $\begin{array}{l}\text { Qld., N.T., W.A., north of c. } \\
26^{\circ} 50^{\prime} \text { S. latitude. }\end{array}$ \\
\hline S. restiacea & glabrous & golden, short & deeply divided & W.A. \\
\hline
\end{tabular}

Coopernookia scabridiuscula Carolin, sp. nov.

Holotype: Cliffs on SE side of Mt. Maroon, Queensland, M. Olsen 374, 23.9.1976 (BRI 218131). ISOTYPE: (SYD).

Suffrutex ad $1 \mathrm{~m}$ alta. Folia anguste elliptica ad oblongo-elliptica (4-) $6-8 \mathrm{~cm}$ longa pilis glandulosis sed ubi adulta scabridiuscula. Flores in racemis bracteolatis basim ovarii vix excedentibus. Corolla malvina pilis stellatis et glandulosis extus 15-16 mm longa lobis ac fauce barbatis. Capsula seminaque ignota.

Weak branching shrub to $1 \mathrm{~m}$ high. Stems glandular hairy when young. Leaves narrow- to oblong-elliptic (4-) 6-8 cm long, 5-10 $\mathrm{mm}$ wide, glandularpubescent when young but becoming minutely scabrid with age, dentate, acute to acuminate, base attenuate with a short indistinct petiole; margin slightly recurved particularly towards the base and apex. Flowers arranged in terminal leafy racemes; pedicels $10-15 \mathrm{~mm}$ long with two linear bracteoles which scarcely exceed the base of the ovary inserted about the middle, indistinctly articulated between the bracteoles. Sepals ovate to lanceolate, 5-6 $\mathrm{mm}$ long, $1.5-2 \mathrm{~mm}$ wide, acute, adnate to the lower half of the ovary, glandular-pubescent. Corolla "pink-purple", 15-16 mm long, stellate and glandular-pubescent outside, villous towards the base inside and with rows of long psuedo-hairs (barbulae) on the lobes and extending into the throat; superior lobes narrow-elliptic, $10-12 \mathrm{~mm}$ long, c. $1.5 \mathrm{~mm}$ wide with a wing c. $2 \mathrm{~mm}$ wide on either side making an obtuse angle at the apex; inferior lobes narrow-elliptic to oblanceolate, $9-10 \mathrm{~mm}$ long and c. $2 \mathrm{~mm}$ wide with a wing c. $2 \mathrm{~mm}$ wide and c. $6 \mathrm{~mm}$ long on either side; connate part of the inferior lobes c. $4 \mathrm{~mm}$ long; anterior pocket not very prominent but about half as long as the ovary. Stamens 5, free; filaments linear, 3-4 mm long; anthers oblong, $1.5 \mathrm{~mm}$ long, obtuse. Ovary glandularpubescent with an almost obsolete dissepiment bearing 2-4 ovules; styles $9-10 \mathrm{~mm}$ long, villous; indusium depressed-ovate $1.5 \mathrm{~mm}$ long, $2-2.5 \mathrm{~mm}$ wide, villous with long white bristles on the lips. Capsule and seeds not seen.

This species has an apparently restricted distribution, and is distinguished from $C$. barbata by having broader and altogether larger leaves and shorter bracteoles; from C. chisholmii it differs in not having stellate hairs on the leaves. It is known only from the Mt. Maroon region in Queensland near the border with New South Wales.

Specimen Examined: QueEnsland: Mt Maroon, S. L. Everist 7053, 28.1.1962 (BRI 04427). 
Verreauxia verreauxii (De Vriese) Carolin, comb. nov.

Basionym: Dampiera verreauxii De Vriese, Nat. Verh. Holl. Maats. Wet. Haarlem 10: 118, t. 20 (1854).

TYPE: Verreaux (P).

Absolute Synonym: Verreauxia paniculata Benth., Fl. Austral. 4: 105 (1869), nom. superfl.

TYPE: as for Dampiera verreauxii.

When Bentham described $V$. paniculata he listed Dampiera verreauxii De Vriese as a synonym and therefore the former is a superfluous name.

\section{ACKNOWLEDGEMENTS}

I would like to thank Dr L. A. S. Johnson for checking the Latin descriptions and Miss A. Graham for typing the manuscript.

\section{REFERENCE}

Krause, L. (1912). Goodeniaceae und Brunoniaceae. 'Das Pflanzenreich'. Heft 54. (Engelmann: Leipzig).

Manuscript received 5.9.1979 